\title{
PRESENTEEISM OF CLASS TEACHERS: WELL-BEING AS A CRITICAL PSYCHOLOGICAL STATE IN THE MEDIATION OF JOB CHARACTERISTICS
}

\author{
AMALIA R. PÉREZ-NEBRA ${ }^{1,2}$ \\ http://orcid.org/0000-0001-8386-1233 \\ FABIANA QUEIROGA ${ }^{1}$ \\ http://orcid.org/0000-0002-3811-8202 \\ THIAGO A. OLIVEIRA ${ }^{1}$ \\ (iD) http://orcid.org/0000-0002-7772-6622
}

To cite this paper: Pérez-Nebra, A. R., Queiroga, F., \& Oliveira, T. A. (2020). Presenteeism of class teachers: Well-being as a critical psychological state in the mediation of job characteristics. Revista de Administração Mackenzie, 21 (1), 1-26. doi:10.1590/1678-6971/eRAMD200123

Submission: June 15, 2019. Acceptance: Nov. 14, 2019.

1 Centro Universitário de Brasília (UniCEUB), Brasília, DF, Brazil.

2 Universidad Internacional de Valencia (VIU), Valencia, Spain.

\section{(c) $\mathbf{B Y}$}




\section{ABSTRACT}

Purpose: Test job fulfillment as a mediator of the relationship between work design and presenteeism in teachers.

Originality/value: Presenteeism is one of the reasons for teachers to underperform in the classroom. Many models explain organizational results, among which the Job Characteristics Model. That model, however, has not yet been tested with presenteeism, and, as it proposes, it will be predicted by work design mediated by positive work-related attitudes (i.e., eudaimonic well-being).

Design/methodology/approach: A total of 2,282 public school teachers participated in the study, of which $71.1 \%$ were women. They completed the scale of job fulfillment, the Stanford Presenteeism Scale, and the full work design taxonomy in the Brazilian version. Direct and mediated relationships were tested, and the Job Characteristics Model was partially confirmed.

Findings: For not completing work, mediation is confirmed only to the task identity subcategory of work design. Here, direct relationships with scheduling autonomy and social support were observed. For avoiding distraction, mediation occurred only for social support, and comfort at work. The subcategories decision-making autonomy, physical demands, and job complexity are directly related. We discuss the mediating role of critical psychological states and other positive triggers that could mediate the relationship between work design and organizational outcomes, such as emotions.

\section{KEYWORDS}

Presenteeism. Work design. Well-being. Teachers. Job Characteristics Model. 


\section{INTRODUCTION}

Education is one of the basic rights granted to individuals and ensured in the Brazilian Federal Constitution. Society can flourish through education. In this scope, teachers play a core role as one of the mainstays of the formal learning process. Some factors can and do influence teachers when performing their duties: public policies, pedagogical projects, education guidelines, social and economic aspects, management, job characteristics, relationship with students, and subjective variables (Cotta, 2001). However, how are these factors perceived? Which factors can influence performance gains and losses? The factors that affect teachers' performance, considering their health, and impact their professional performance are discussed in the light of these concerns.

There is a host of situations in which the sickening of the workforce makes them not show up for work. In some cases, however, although feeling ill, they continue working. Staying at work may entail consequences to the workers' performance and affect the possibility of fulfilling the organizational goals and targets. These consequences are even sharper in the school context, as the on-site educational model is based on the teacher-student interaction. Disturbances in that interaction caused by the teachers' sickening harm the process flow and development over the academic year, and can pull down performance, motivation, and links established in the classroom.

The phenomenon known as presenteeism can be defined as workers showing up for work, overlooking the fact that they are not able to perform the duties at full capacity. Presenteeism has been associated with the pressure over workers due to an insecure and uncertain labor market (Araújo, 2012). Both disease-related presenteeism and absenteeism may serve as indicators of uneasiness and sickening. Above all, presenteeism is an indication of loss of productivity caused by physical and mental health issues and is only achievable through self-report measures (Gerich, 2019).

Presenteeism is a long-lasting phenomenon in the work context. However, it was not before the 2000s that this concept started calling attention, since a publication by Hemp (2004). Investigating presenteeism is not an easy task, as it is not always apparent, conversely to absenteeism. It is worth mentioning that presenteeism is not a mere opposition to absenteeism. Johansen, Aronsson, and Marklund (2014) understand presenteeism as showing up for work even feeling sick; but others understand presenteeism as "absenteeism being present at work" (Hemp, 2004). 
Presenteeism has significant impacts on the workers' performance, and may reduce their productivity with severe after-effects on individuals and in the work context. In addition to productivity, it may also affect organizational expenditures with health plans, medical expenses, leaves and compensations (Ozminkowski, Goetzel, Chang, \& Long, 2004).

Some instruments were developed to investigate presenteeism. Pereira (2014) found more than 25 different instruments to measure the phenomenon. One of the instruments most largely used is the Stanford Presenteeism Scale - SPS-6 (Koopman et al., 2002) in the version adapted to Portuguese Ferreira, Martinez, Souza, and Cunha (2010); to the Portuguese of Portugal; and Frauendorf, Pinheiro, and Ciconelli (2014); Paschoalin, Griep, Lisboa, and Mello (2013) to the Brazilian Portuguese. That scale evaluates presenteeism based on two factors: (not) completing work and avoiding distraction. The first factor, completing work, refers to the work quantitative perceived as completed by workers under the effect of presenteeism. Avoiding distraction, in turn, concerns the worker's concentration effort to perform the job.

Some studies approach the topic of presenteeism in the Brazilian context. A comparison among different types of occupation reveals that presenteeism is stronger in education (Lourenço, 2016; Sousa, 2016). Presenteeism is explained by variables such as organizational commitment (Sousa, 2016; Xavier, 2015), and women seem to be more affected than men (Sousa, 2016).

Based on the results of other presenteeism-related surveys with teachers, it was found that more than $27 \%$ (Xavier, 2015) or than $60 \%$ (Porto, Almeida, \& Teixeira, 2013) of participants report to show up for work even when they are sick. As regards job nature and characteristics and occupational health conditions, the report disseminated by the International Labour Organization (ILO) in 2013 points out that care costs involving health plan, medicine, disability, compensations, etc., and losses to the organization and workers are very high. In 2012, the global Gross Domestic Product (GDP) loss due to occupational accidents and diseases was estimated at $4 \%$, equivalent to 2.8 billion dollars (ILO, 2013). According to the report, the most common diseases related to teachers' work are musculoskeletal conditions and mental disorders.

Regardless of what has been reported regarding the Brazilian scenario, the difficulties brought up are not exclusive to Brazil. Diehl, and Marin (2016) carried out a bibliographic review on teachers' mental diseasing, from 2010 to 2015, and analyzed 15 essays. They found that burnout is one of the most investigated symptoms. The burnout dimensions usually 
investigated are: emotional exhaustion, depersonalization and low job fulfillment. The first variable is emotional, while the second is related to coping strategy, and the third is related to attitude towards work.

Although the discussion about stress and work is commonplace, this issue is of special relevance when applied to the teaching activity. Teaching is an extremely demanding activity that generates high levels of stress (Abacar, Roazzi, \& Bueno, 2017; Moreira, 2015). Educational reforms are one of the factors considered relevant for teachers' diseasing process. Grounded on bureaucratic and technicist biases, these started demanding much more from professionals without providing the required material conditions to meet these demands (Croon, Veldhoven, Peccei, \& Wood, 2015; Vieira, 2017; Xavier, 2015). This made teachers' work more demanding than ever, and some teachers, for the abovementioned reasons, many times do not perform as expected or perform the work in an exhaustive way, with implications for their health (Gomes, 2002).

Many models found in literature try to explain the consequences on work. Typically, the models attempt to explain performance at work, and, making an analogy to this case, presenteeism could be considered as a perception of (loss of) performance. Three major perspectives in performance can be characterized: individual, situational and regulatory (Sonnentag \& Frese, 2002). The situational performance refers to the environment influencing performance. It entails practical advantages over the others, as the organization increases control on how to improve processes. Moreover, the change on teachers' work design and demands suggest that the Job Characteristics Model (JCM) (Hackman \& Oldham, 1975, 1976) is the one that fits best. The JCM proposes three stages: organizational outcomes would be predicted by critical psychological states, and, in its turn, these psychological states by job characteristics, i.e., positive attitudes and these, in turn, would be predicted by core job characteristics. Critical psychological states encourage workers to keep on feeling well at work and wanting to perform well (Hackman \& Oldham, 1976). Figure 1.1 summarizes the model. Motivation at work is the assumption of this model. 


\section{(Figure 1.1)}

\section{SUMMARIZED JOB CHARACTERISTICS MODEL BY HACKMAN AND OLDHAM (1975)}

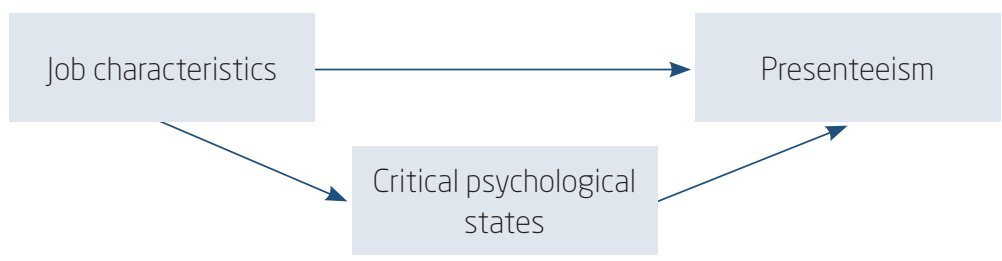

Source: Elaborated by the authors.

The core proposal that job characteristics affect attitudinal outcomes is very consistent in the literature (Parker, 2014). Although the JCM mediating variables are minimally supported, many personal characteristics confirm the JCM overall idea (Morgeson \& Campion, 2003; Parker, Holman, \& Johns, 2017). Erez (2010) puts to the question the fact that JCM has been tested and works almost exclusively in the USA, and suggests that the characteristics that motivate a culture may differ from culture to culture, or that critical psychological states could be distinct. In Brazil, for example, the evaluative proposal of work design (Borges-Andrade, Peixoto, Queiroga, \& Pérez-Nebra, 2019) was organized in a quite different way in comparison to the proposal by Morgeson and Humphrey (2006). Despite the questions raised by Erez (2010) regarding this model, the idea that job characteristics act as motivators in different ways in different cultures had already been posed (Tannenbaum, 1980).

Broeck and Parker (2017) made some criticisms to the JCM. The first is that the model includes only some aspects of work. Work orientation was a motivator and positive, but it disregarded demands. In other words, in the line of the Demands-Resources Model (Lesener, Gusy, \& Wolter, 2019; Schaufeli, 2017) the JCM was exclusively oriented to resources. Other criticism, more to the support in literature than to the model, is that critical psychological states are weakly linked to outcomes (Renn \& Vandenberg, 1995), and relationships have been worked in a straightway. Although the literature supports the direct model robustness, relevant theoretical and practical information should be considered regarding critical psychological states, and the authors identified other mediators and moderators (Oldham, 1980 as mentioned in Broeck \& Parker, 2017; Weiss \& Cropanzano, 1992).

According to Hackman and Oldham $(1975,1976)$, there are three critical psychological states: 1. work meaningfulness, i.e., the work is meaningful, 
valued and worthy; 2. responsibility for outcomes, i.e., the individual is responsible for their work; and 3. knowledge of outcomes, i.e., awareness of how the effective one is in the work. In other words, these are positive attitudes resulting from work; one could say these are eudaimonic aspects of work. The eudaimonic aspects of work could be translated in many ways, but Paschoal and Tamayo (2008) put it as one of the aspects of well-being at work, the job fulfillment.

In the last few years, studies on well-being have been more intensively driven by the hedonist and eudaemonist currents (Santos \& Ceballos, 2013). These currents concern positive subjective states and parallel to the understanding of happiness. The hedonist concept of happiness is based on the experience of pleasure versus displeasure. This proposal is grounded on the analysis of positive and negative elements of life. The eudaemonist perspective, in turn, goes beyond the idea of happiness, also comprising the dimension of personal fulfillment and fundamental life targets (Paschoal \& Tamayo, 2008).

Literature indicates an increasing interest in investigation and conceptual proposals to the topic (Paschoal \& Tamayo, 2008; Siqueira \& Padovam, 2008; Paschoal, Torres, \& Porto, 2010; Rocha \& Porto, 2012). Within the Brazilian context, it is noticeable the relevance of the proposal by Paschoal and Tamayo (2008) that tried to incorporate both hedonic and eudaimonic functions of well-being at work in the measuring of well-being at work. Although the authors acknowledge the role played by positive and negative emotions, the JCM includes only attitudinal aspects and, in this case, job fulfillment. It is in this dimension that the perception of expressivity is assessed, i.e., how individuals express themselves through work to get satisfied, and the individual's job fulfillment that basically corresponds to which extent individuals feel fulfilled in the performance of their tasks and activities (Paschoal \& Tamayo, 2008).

Molina et al. (2017) developed a study on well-being in the school context, comprising teachers and aimed at verifying the prevalence of wellbeing and its relationship with other variables, namely: socio-demographic characteristics, health and work conditions, and vocal behavior. Results disclosed prevalence of satisfactory perceptions of well-being among teachers (79.5\%) and that the number of students in the classroom was one of the factors inversely associated with the perception of well-being.

In the classical proposal by Hackman and Oldham (1976), the JCM proposed five core job characteristics (skill variety, task identity, task significance, autonomy, and feedback from the job). These have been adopted to explain behavior at work and the desired results to the organization such 
as reduced turnover, increased motivation and worker's satisfaction. Despite the relevance and applicability of the authors' proposal, job fulfillment is not limited to those characteristics, considering that there are other aspects related to the creation and modification of the work composition, content, structure and the environment in which tasks and roles are performed (Parker et al. 2017).

This set of broader characteristics was named work design. In a review of classic models that characterize work, Morgeson and Humphrey (2006) present a taxonomy of work design and specific measures to their categories and subcategories (Work Design Questionnaire - WDQ). Several national instruments aim to measure work conditions (e.g., Borges et al., 2013), but the constructs they work with do not match the work design construct. The WDQ has already been adapted and used in many countries. In Brazil, the instrument is composed of 18 factors (Borges-Andrade et al., 2019) that comprise three categories originally proposed by Morgeson e Humphrey (2006), namely motivational, social and contextual characteristics.

In general, the motivational characteristics assume that higher levels of motivation lead to a higher perception of work as fulfilling. This dimension is divided into characteristics of task and knowledge. The social characteristic is about the extent and effects of Completing Work on a broader social context. Lastly, the contextual category is related to the physical and environmental aspects in which work is performed (Morgeson \& Humphrey, 2006). Figure 1.2 depicts the characteristics and their subdimensions.

The 5-factor task characteristics assume that critical psychological states can be produced in the office. The first three aspects (task variety, task identity and task significance) may lead to enhanced work meaningfulness. Autonomy develops higher responsibility for work outcomes, while feedback would be related to awareness about the results of activities performed at work.

The studies that comprise work design variables in the light of Morgeson and Humphrey (2006) evince to which extent this aspect can affect the many job aspects, such as performance (Sampaio, 2018), well-being (Rocha \& Porto, 2012; Cruz, 2014) and health (Molina et al., 2017). Cruz (2014) developed a study in Portugal aimed to analyze which work design factors would more strongly influence well-being at work. Results show that motivational and social dimensions were more closely related to the construct of well-being. Thus, the higher the perceptions of motivational dimensions, notably the factors of task variety $(r=0.54 ; p<0.01)$, work scheduling autonomy $(r=0.54 ; p<0.01)$ and decision-making autonomy $(r=0.60$; $p<0.01)$, the higher the perceptions of well-being. The same was found to the social dimension, more specifically to social support characteristics $(r=$ $0.60 ; p<0.01)$. 


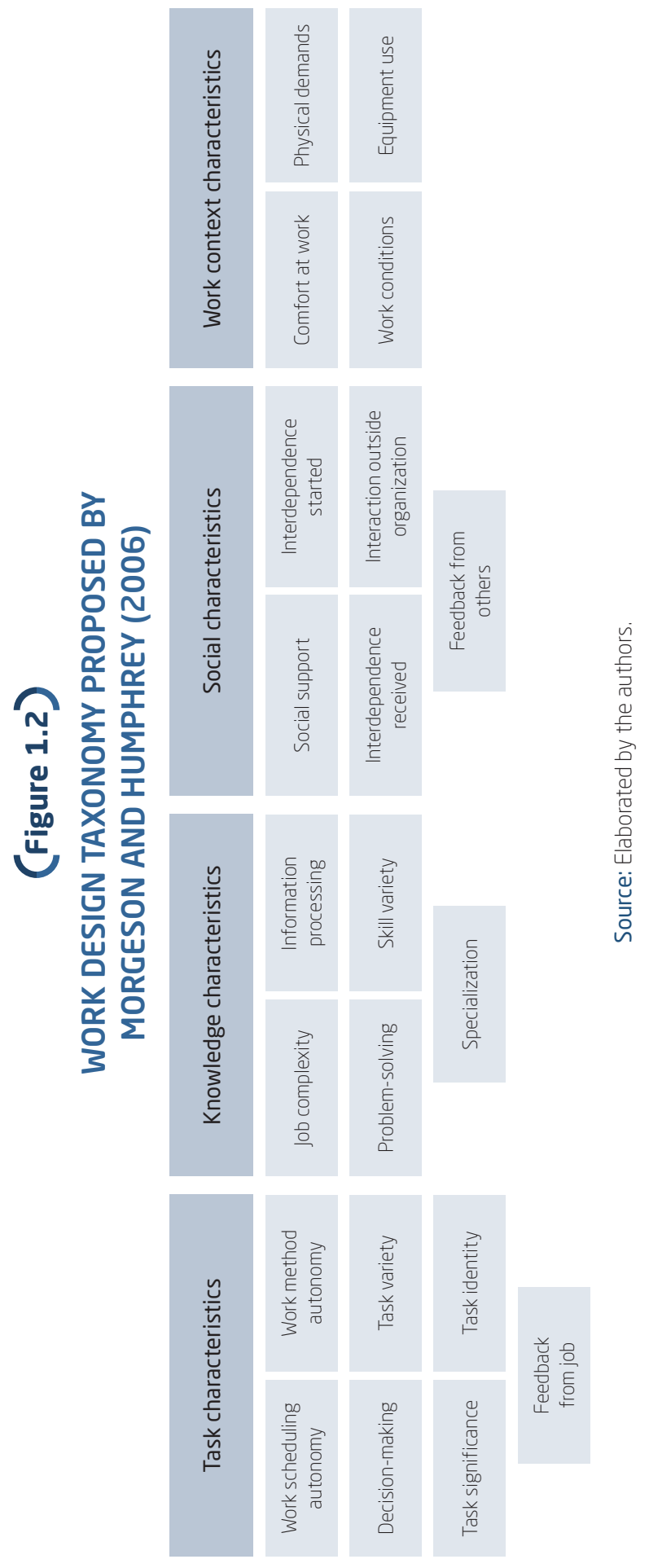


This study aimed to test job fulfillment as a mediator of the relationship between work design and presenteeism among class teachers, applying the JCM. Results are expected to expand the understanding on the dynamic of factors and conditions involving the quality of services delivered by teachers, in addition to aspects related to their health. This survey is innovative in several dimensions: the first one is that it tests the JCM in the Brazilian school context - the model has been tested in the school context of Ontario (Guise, 1988). Secondly, it includes presenteeism as an organizational outcome in JCM. The third dimension is that it considers the eudaimonic dimension of well-being as a critical psychological state, expanding the scope of the original proposal by Hackman and Oldham $(1975 ; 1976)$, in compliance with what is suggested by the literature (Parker, 2014; Parker et al., 2017; Broeck \& Parker, 2017). Finally, it includes it testing the whole range of work design taxonomy introduced by Morgeson and Humphrey (2006).

\section{METHOD}

\subsection{Participants}

This survey used the valid responses of 2,282 teachers assigned to public schools. Most participants were women $(71.1 \%)$, married individuals $(60.7 \%)$, and the overage age mean was $47(\mathrm{SD}=13.71)$. Although $16.2 \%$ of the responses did not inform the school of origin, $4.3 \%$ of the participants reported to be assigned to rural schools, and the remaining are from urban schools. Collection was online $(83.8 \%)$ and paper-and-pencil.

Teachers of activities, i.e., teachers of the first cycle of the Brazilian primary education, account for $40.3 \%$ of the sample, followed by language teachers (arts, physical education, Portuguese, foreign language and music), that responded for $31.7 \%$. The other teachers deliver subjects of human sciences and mathematics.

\subsection{Instruments}

- Presenteeism: made up of two factors: (not) completing work and avoiding distraction (Ferreira et al. 2010). Presenteeism is composed of six items, being three items to each factor. Responses were on a 5-point agreement scale where the NA (not applicable) response excluded the participant, 
because they report to have not experienced presenteeism. Although existing, NA responses are rare.

- Job fulfillment: is the well-being attitudinal dimension, as proposed by Paschoal and Tamayo (2008). The scale used in this study is a unifactorial brief version of the original scale. Five items were selected following the criterion of factor loading in the original study. The response scale is a 5-point agreement scale.

- Work design: the Brazilian version of Morgeson's and Humphrey's (2006) WDQ, adapted by Borges-Andrade et al. (2019), was used. The questionnaire comprises 71 questions divided into 18 subcategories and four categories (task characteristic, knowledge characteristic, social characteristics, and work context). The 5-point agreement scale was also used.

- A socio-demographic questionnaire was applied to characterize the participants' profiles.

\subsection{Procedures}

The online questionnaire link and the Informed Consent Form (ICF) were sent to the general coordinator of the people management sector of the public body. The general coordinator then retransmitted the e-mail to the active class teachers. Few questionnaires were applied in the pencil-and-paper format $(16.2 \%)$, with the assistance of the regional coordinators, to reach rural schools $(4.3 \%)$ and teachers with no access to the internet, for example.

\subsection{Data analysis}

The Statistic Package for Social Science (SPSS) and Hayes process were used to analyze the data. Data curation was on the Excel and then on the SPSS. Analyses revealed good reliability for all scales and scarce normality problems. Missing data were excluded from the sample. The same procedure described by Renn and Vandenberg (1995) and Preacher, Rucker, and Hayes (2007) was used to test the model: entry of the antecedent variable in separate and then entry in sequence to confirm mediation.

The association between the variables to be included in the model was certified before starting the regression analyses. In operational terms, significant and more expressive correlations were found. It is worth mentioning that, considering that the sample size tends to amplify magnitudes, the criterion of correlations above $|0.12|$ was applied to hold associations, assuming the interval between correlations. 
The mediation effects were interpreted according to the steps defined by Baron and Kenny (1986):

- Step 1: relationship between the predictor variable (VI) and the criterion variable (VD) must be significant.

- Step 2: the VI must be related to the mediator variable.

- Step 3: the mediator must be related to the VD after the effect of the predictor is controlled.

- Step 4: the strength of the association between the VI and VD must be lessened when the model considers the mediator.

Following the literature recommendations (Baron \& Kenny, 1986), the first step was to perform regressions between presenteeism and work design (considering only the variable held in the correlation analysis). The second step was to analyze the prediction between presenteeism and eudaimonic well-being (job fulfillment). The third step consisted of analyzing the relationship between the mediator variable and the VD after controlling the effect of predictor variables. To that, hierarchical linear regression was performed, including job fulfillment in the first block, and work design factors held were included in the second block. With the variables that presented a relationship, the next step was the mediation test, which used the Hayes package, model 4 .

\section{RESULTS}

Data indicated that teachers' perceptions about presenteeism were not high, mainly that of not completing work. Avoiding distraction, however, is more prevalent. The perception of job fulfillment is above the mean point of the scale. As regards work design, the means shown in Figure 3.1 reinforce what has been described as the teacher's work. Teacher's work is perceived as little interdependent (mean $=2.65, \mathrm{SD}=1.06$ ), i.e., teachers are little dependent from the others to perform their tasks, and their perception of context can be improved, considering that all means in this category are below the mean point of the scale: comfort, physical demands, work conditions, and equipment use. 


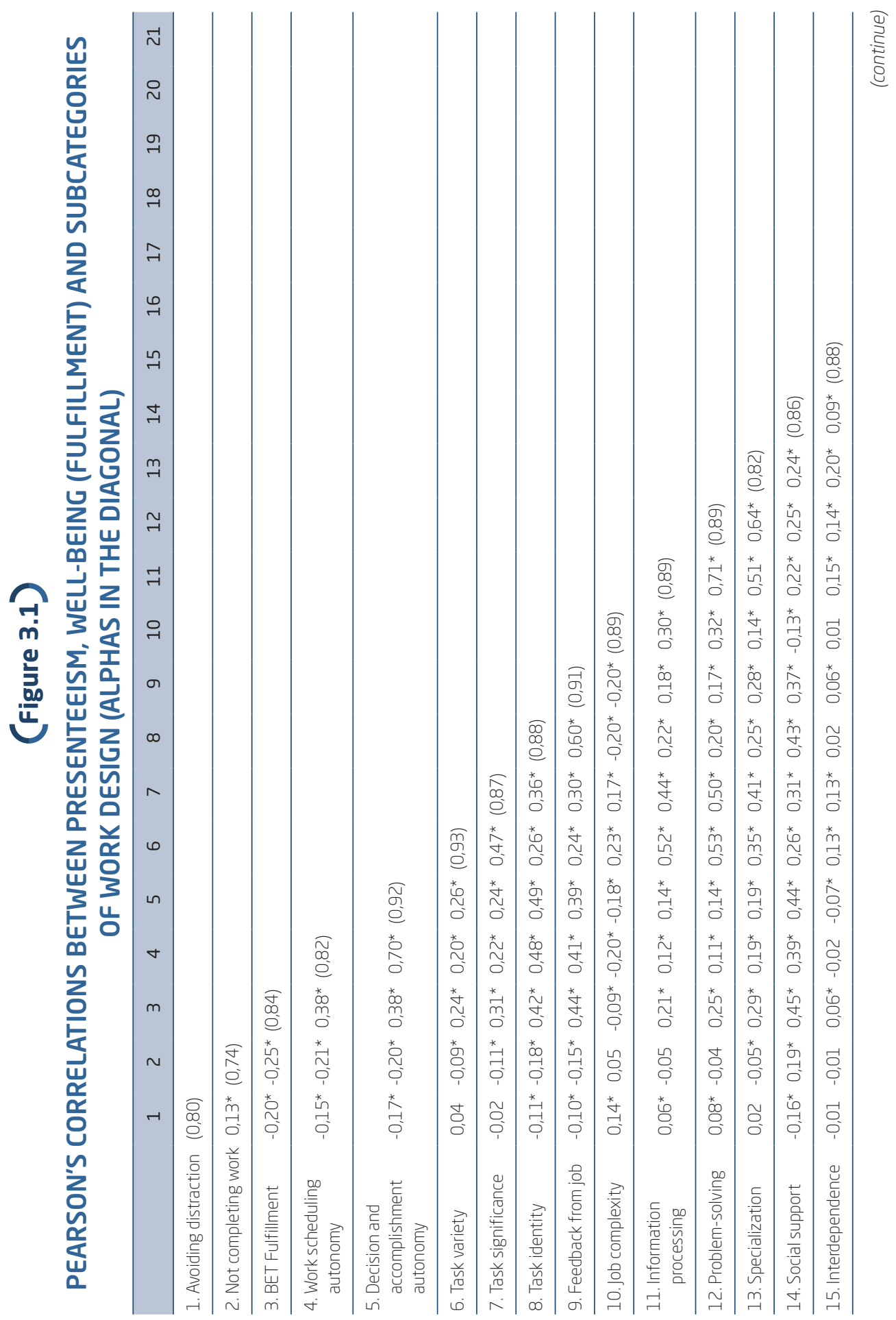




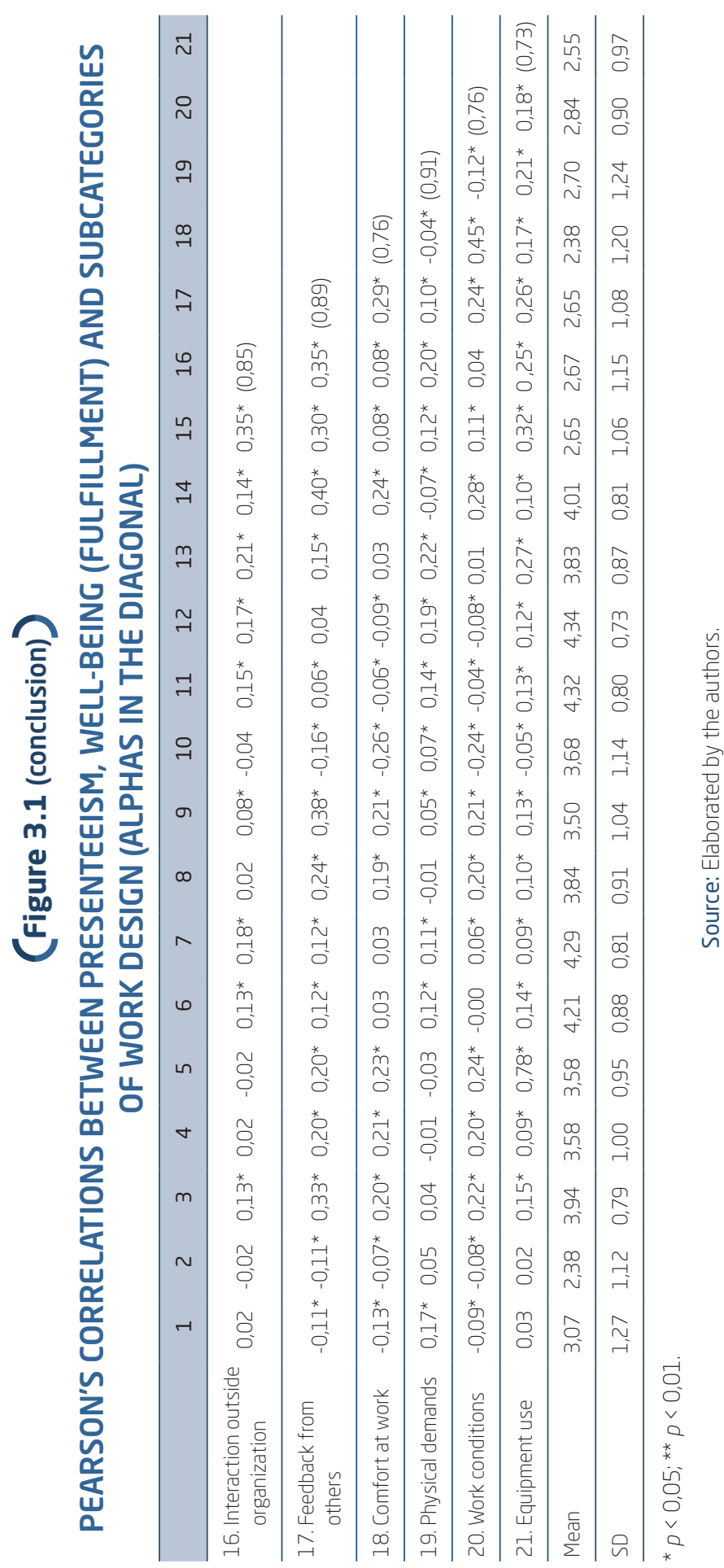


It is worth mentioning that, despite the negative perceptions, the mean in Task significance is quite high, as well as those for the other factors that make up the category of Task Characteristic. The relationships between presenteeism and job fulfillment are not strong, suggesting that mediations could be weak. Presenteeism does not report strong correlations with the work design categories, differently from job fulfillment, where relationships are more intensive. Following are the results of the regressions where the effect of job fulfillment is controlled.

(Figure 3.2)

RESULTS OF THE HIERARCHICAL REGRESSION APPLIED TO THE ANALYSIS OF PREDICTORS OF AVOIDING DISTRACTION

\begin{tabular}{|c|c|c|c|c|c|c|}
\hline \multirow{2}{*}{ Antecedent variables } & \multicolumn{3}{|c|}{ Step $1^{\star}$} & \multicolumn{3}{|c|}{ Step 3} \\
\hline & Beta & $\mathrm{t}$ & $p<$ & Beta & $\mathrm{t}$ & $p<$ \\
\hline Job fulfillment & - & - & - & -0.15 & $-4,92$ & 0,00 \\
\hline Work scheduling autonomy & -0.06 & -1.25 & 0.21 & - & - & - \\
\hline Decision-making autonomy and fulfillment & -0.10 & -2.04 & 0.04 & -0.07 & $-2,46$ & 0,00 \\
\hline Job complexity & 0.10 & 3.04 & 0.01 & 0.09 & 3,24 & 0,01 \\
\hline Social support & -0.12 & -2.54 & 0.01 & -0.03 & $-0,91$ & 0,36 \\
\hline Comfort at work & -0.06 & -1.98 & 0.05 & -0.04 & $-1,45$ & 0,15 \\
\hline Physical demands & 0.15 & 5.52 & 0.01 & 0.16 & 6,00 & 0,01 \\
\hline Multiple regression coefficient & \multicolumn{3}{|l|}{$R=0.27$} & \multicolumn{3}{|l|}{$R=0.30$} \\
\hline Explanation of variability & \multicolumn{3}{|c|}{ Adjusted R2 = 0.07} & \multicolumn{3}{|c|}{ Adjusted R2 = 0.08} \\
\hline Statistical test & \multicolumn{3}{|c|}{$F(6 / 1417)=18.71 ; p<0.001$} & \multicolumn{3}{|c|}{$F(6 / 1417)=22.76 ; p<0.001$} \\
\hline
\end{tabular}

* Step Z: job fulfillment has adjusted $R^{2}$ of $0.04 ; F=-7.54 ;$ Beta $=-0.20 ; p<0.001$.

As can be inferred from Figure 3.2, the indexes of significance presented in steps 1 and 3 suggest that only social support and comfort at work lose the predictive power when controlled by job fulfillment. Decision-making autonomy and fulfillment, job complexity and physical demands reported direct relationship with avoiding distraction. The same procedure was carried out to the second factor of presenteeism, not completing work. Results are presented in Figure 3.3. 


\section{(Figure 3.3)}

RESULTS OF THE HIERARCHICAL REGRESSION APPLIED TO THE ANALYSIS OF PREDICTORS OF NOT COMPLETING WORK

\begin{tabular}{|c|c|c|c|c|c|c|}
\hline \multirow{2}{*}{ Antecedent variables } & \multicolumn{3}{|c|}{ Step $1^{*}$} & \multicolumn{3}{|c|}{ Step 3} \\
\hline & Beta & $\mathrm{t}$ & $p<$ & Beta & $\mathrm{t}$ & $p<$ \\
\hline Job fulfillment & - & - & - & $-0,22$ & $-4,67$ & 0,00 \\
\hline Work scheduling autonomy & -0.12 & -2.93 & 0,01 & $-0,10$ & $-2,60$ & 0,00 \\
\hline Decision-making autonomy and fulfillment & -0.06 & -1.33 & 0,18 & - & - & - \\
\hline Task identity & -0.07 & -1.89 & 0,05 & 0,04 & 0,64 & 0,52 \\
\hline Feedback from job & -0.03 & -1.04 & 0,30 & - & - & - \\
\hline Social support & -0.12 & -2.85 & 0,01 & $-0,07$ & $-2,27$ & 0,02 \\
\hline Multiple regression coefficient & \multicolumn{3}{|l|}{$R=0.25$} & \multicolumn{3}{|l|}{$R=0.22$} \\
\hline Explanation of variability & \multicolumn{3}{|c|}{ Adjusted R2 = 0.06} & \multicolumn{3}{|c|}{ Adjusted R2 = 0.05} \\
\hline Statistical test & \multicolumn{3}{|c|}{$F(5 / 1469)=19.46 ; p<0.001$} & \multicolumn{3}{|c|}{$F(4 / 1416)=18.44 ; p<0.001$} \\
\hline
\end{tabular}

* Step 2: job fulfillment - has adjusted $R^{2}$ of 0.06; $F=-10.05 ;$ Beta $=-0.25 ; p<0.001$.

Source: Elaborated by the authors.

As can be inferred from Figure 3.3, when comparing the indexes of the significance of steps 1 and 3, only task identity loses its predictive power when job fulfillment is included in the regression. The work scheduling autonomy and social support are directly related to not completing work. According to the steps defined by Baron and Kenny (1986), only the variables that lose their predictive power are included in the mediation model. Next, we moved on to the mediation models to each criterion variable, i.e., presenteeism factors. Avoiding distraction was the first one.

The graphic representation of Figure 3.4 shows the first mediation relationship tested. The mediation of the well-being critical psychological state (job fulfillment) was tested for avoiding distraction with social support $\left(\mathrm{R}^{2}=0.05 ; \mathrm{F}=33.45 ; p<0.001\right.$; indirect effect $=-0.11$; Lower bootstrap $=$ -0.15 ; Upper bootstrap $=-0.07)$ and comfort at work $\left(\mathrm{R}^{2}=0.05 ; \mathrm{F}=34.03\right.$; $p<0.001$; indirect effect $=-0.04$; Lower bootstrap $=-0.06$; Upper bootstrap $=$ -0.03) and is confirmed in both cases.

The second mediation test, depicted in Figure 3.5, was for not completing work. 


\section{(Figure 3.4)}

\section{TEST OF THE JCM FOR AVOIDING DISTRACTION}

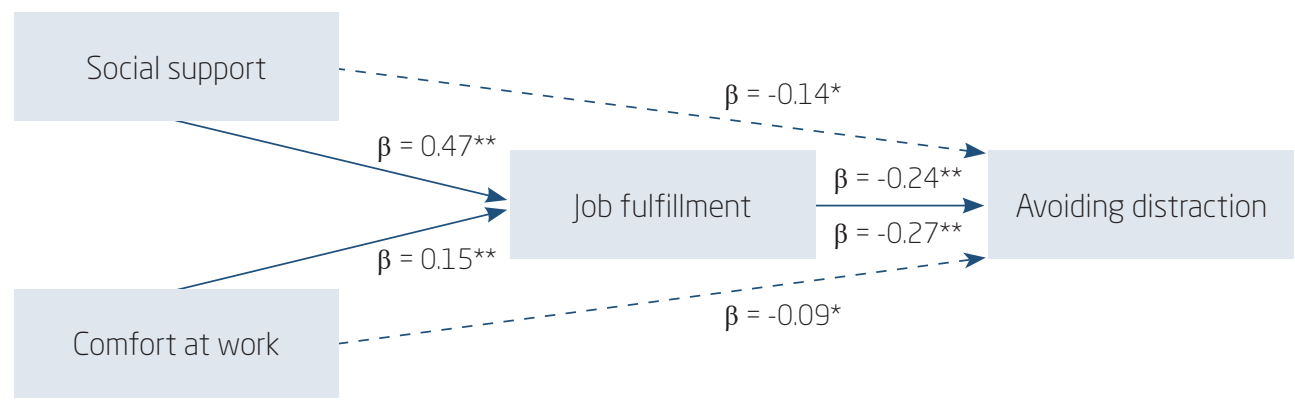

The betas above refer to social support, below the arrows of comfort at work.

${ }^{*} p<0.05 ;{ }^{* \star} p<0.001$

Source: Elaborated by the authors.

(Figure 3.5)

JCM FOR COMPLETING WORK

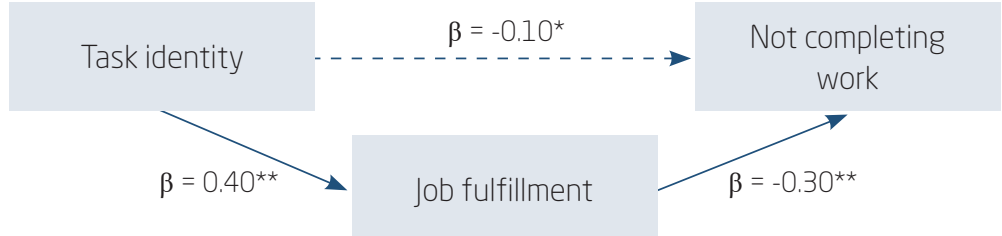

${ }^{*} p<0.05 ;{ }^{* *} p<0.001$

Source: Elaborated by the authors.

As can be observed, the mediation analysis with task identity $\left(\mathrm{R}^{2}=\right.$ $0.07 ; \mathrm{F}=55.13 ; p<0.001$; indirect effect $=-0.12$; Lower bootstrap $=-0.15$; Upper bootstrap $=-0.08$ ) is also confirmed. The values observed, however, show that relationships between work design and presenteeism seem to be rather direct than mediated by critical psychological states such as job fulfillment.

\section{DISCUSSION}

This study aimed to test job fulfillment as a mediator of the relationship between work design and presenteeism among class teachers, applying the 
JCM. The model is considered successfully applied to the Brazilian educational contexts and was partially supported by the data found. The interpretation of presenteeism as an organizational outcome remains a challenge, but it is related to several work design variables, both mediated and directly related. Lastly, job fulfillment understood as a critical psychological state in the JCM seems to be acceptable since it mediated some relationships found between work design and presenteeism, thus, expanding the scope of the original model.

Avoiding distraction presented more intensive results in general, either in the magnitude of the phenomenon itself (i.e., highest mean $=3.07$ ) and in the higher number of work design variables that could explain the dimension. In addition, avoiding distraction reported both demand and resources variables as predictors, what did not happen with not completing work. An explanatory hypothesis to this result is that teachers, for the nature of their activity (intellectual and teaching), perceive when keeping concentration is more costly. Differently from not completing work (mean $=2.38$ ) that, also due to the task nature, can hardly define to which extent teachers could not complete the task because of health problems, the task may have been completed, but the problem may regard the quality of such task, which is a major challenge of education (Croon, Veldhoven, Peccei, \& Wood, 2015).

The new work design taxonomy makes an important contribution to explain the organizational outcomes and support Parker's criticisms to the models. Parker criticizes the fact that variables are sometimes presented as demands and other times as a resource (Parker, 2019; Broeck \& Parker, 2017). This criticism, however, may have a flaw, since the mediated variables were exclusively for resources, namely: social support and comfort at work for avoiding distraction, and task identity for not completing work. Job fulfillment has not mediated any demand variable for avoiding distraction: job complexity and physical demands. Not completing work presenteeism did not report any work design subcategory as demanding. Once again, this result can be explained by the nature of the teacher's work and their perception of it.

Here, well-being was operated by job fulfillment that, although innovative and quite different from the original proposal by Hackman and Oldham (1975), remains an attitudinal dimension of work. Other variables, like emotions, could be tested as critical psychological states. According to Weiss and Cropanzano's (1996) model, context predicts organizational results mediated by emotions and attitudes at work. Applied to this case, the work design could explain presenteeism mediated by positive and negative affects at work, as well as by job fulfillment, considering that our focus is the fullest 
well-being as a mediator in organizational results. This proposal is out of the scope of this study and is proposed for a future agenda.

It is worth mentioning that although the teachers' sample is one of the strongest points of this study, and scales presented good reliability indexes, the relationship between variables was relatively weak in magnitude. Although job fulfillment can prevent presenteeism, betas are discreet (-0.15 and -0.22). Likewise, job characteristics could also explain presenteeism, with beta that did not reach 0.15 (except for physical demands for avoiding distraction). Considering the sample size and measures quality, we could expect that more variables were found in greater magnitude. This result sheds light to the model used, to the operationalization selected and to the sample.

The JCM has already being criticized in literature, and it would be no novelty if it presents relatively weak results, although it has not been operated strictly in the same way. This makes room and opens an agenda to the need for systematic replication (Zwaan, Etz, Lucas, \& Donnellan, 2018). Although the measures selected were in the scope of the model conceptual development, they could suggest an openness to another type of personal and work outcome, testing not only self-report variables, but also including absenteeism and turnover, as provided for in the original model by Hackman and Oldham (1975). Finally, regarding the sample, there are some hypotheses that, although out of the scope of this study, came about as a result of the findings: will teachers out of the school context, or that are not in-class, report different relationships between variables? Could they be generating disturbance? Would teachers from different cycles and subject groups have different perceptions or relationships between variables? Answering these questions could help managers to better fit the school context to the demands of those teachers and should be included in a future agenda.

Despite the contributions and considerations provided by this study, it also has limitations. Among these, the natural limitations of a work that comprises self-report and cross-sectional variables. Notably, the crosssectional collection for a proposal in stages seems to be an important limitation, as phenomena may entail different repercussions. Despite these limitations, phenomena are relatively stable over time and, regardless of the 3 or 6 month-intervals, the perception of work design, presenteeism and well-being remained quite similar to those reported in a cross-sectional way. The contribution of this study reached several scopes. It succeeded in testing the JCM in the Brazilian school context, with results similar to those found in literature, i.e., partially supporting the model. It includes presenteeism as an organizational result, presenting variables of context directly and indirectly related to presenteeism, including some variables of demand and 
others of resource. It used an attitudinal dimension of well-being and job fulfillment and mediated the variables of resource exactly as predicted by the model. Finally, it used the full work design taxonomy in the Brazilian context. It is especially deemed an important contribution, considering that this taxonomy is starting to be spread over the study of work-related psychological phenomena in Brazil.

\section{ACKNOWLEDGMENT}

Grants Coordenação de Aperfeiçoamento de Pessoal de Nível Superior (Capes): 88881.172259/2018-01.

\section{PRESENTEÍSMO DE PROFESSORES REGENTES: BEM-ESTAR COMO ESTADO PSICOLÓGICO CRÍTICO NA MEDIAÇÃO DE CARACTERÍSTICAS DO TRABALHO}

\section{)} RESUMO

Objetivo: Testar a realização no trabalho como mediador da relação entre desenho do trabalho e presenteísmo em professores regentes.

Originalidade/valor: O presenteísmo é uma das formas de perda de desempenho dos professores em sala de aula. Diversos são os modelos que explicam resultados organizacionais, entre os quais o Modelo de Características do Trabalho. Entretanto, este modelo até o presente momento não foi testado com presenteísmo, e, segundo sua proposta, ele será predito pelo desenho do trabalho mediado por atitudes positivas relacionadas ao trabalho (isto é, bem-estar eudaimônico).

Design/metodologia/abordagem: Participaram do estudo 2.282 professores de escolas públicas, dos quais $71,1 \%$ eram mulheres. Responderam à escala de realização no trabalho, à escala Stanford de presenteísmo e à taxonomia completa de desenho do trabalho da versão brasileira. Foram testadas relações diretas e mediadas, e o Modelo de Características do Trabalho confirmou-se parcialmente.

Resultados: Para trabalho não completado, a mediação confirmou-se apenas para a subcategoria identificação da tarefa do desenho do traba- 
lho. Nesse fator, observaram-se relações diretas com autonomia de planificação e suporte social. Para distração evitada, a mediação ocorreu apenas para suporte social e conforto no trabalho. As subcategorias autonomia de decisão, demandas físicas e complexidade do trabalho apresentaram relações diretas. Discute-se o papel mediador dos estados psicológicos críticos e de outros gatilhos positivos que poderiam mediar a relação entre desenho do trabalho e resultados organizacionais, como as emoções.

\section{PALAVRAS-CHAVE}

Presenteísmo. Desenho do trabalho. Bem-estar. Professores. Modelo de Características do Trabalho.

\section{REFERENCES}

Abacar, M., Roazzi, A., \& Bueno, J. M. H. (2017). Estresse ocupacional: Percepções dos professores. Amazônica - Revista de Psicopedagogia, Psicologia escolar e Educação, 19(1), 430-472.

Araújo, J. P. (2012). Afastamento do trabalho: Absenteísmo e presenteísmo em uma instituição federal de ensino superior (Dissertação de mestrado, Universidade de Brasília, Brasília, DF, Brasil). Recuperado de http://repositorio.unb.br/ bitstream/10482/11239/1/2012_JanePereiraAraujo.pdf

Baron, R. M. \& Kenny, D. A. (1986). The moderator-mediator variable distinction in social psychological research: Conceptual, strategic, and statistical considerations. Journal of Personality and Social Psychology, 51 (6), 1173-1182.

Borges, L. O., Costa, M. T. P., Alves-Filho, A., Souza, A. L. R., Falcão, J. T. R., Leite, C. P. R. L. A., \& Barros, S. C. (2013). Questionário de condições de trabalho: Reelaboração e estruturas fatoriais em grupos. Avaliação Psicológica, 12(2), 213-225.

Borges-Andrade, J. E., Peixoto, A. L., Queiroga, F., \& Pérez-Nebra, A. R. (2019). Adaptation of the Work Design Questionnaire to Brazil. Psicologia, Organizações e Trabalho, 19(3), 720-731. doi:10.17652/rpot/2019.3.16837 
Broeck, A. van den, \& Parker, S. K. (2017). Job and work design. Handbook of psychology: Industrial and organizational psychology. Oxford University Press. doi:10.1093/acrefore/978019023557.013.15

Cotta, T. C. S. (2001). Avaliação educacional e políticas públicas: A experiência do Sistema Nacional de Avaliação da Educação Básica. Revista do Serviço Público, 52 (4), 89-111.

Croon, M. A., van Veldhoven, M. J. P. M., Peccei, R., \& Wood, S. J. (2015). Researching individual well-being and performance in context: Multilevel mediational analysis for bathtub models. In M. J. P. M. van Veldhoven \& R. Peccei (Eds.), Well-being and performance at work (pp. 129-151). London \& New York: Psychology Press.

Cruz, C. M. D. (2014). Job design, fatores que influenciam o bem-estar na organização (Dissertação de mestrado, Universidade do Porto, Porto, Portugal). Recuperado de https://repositorio-aberto.up.pt/bitstream/10216/77655/ 2/33705.pdf

Diehl, L., \& Marin, A. H. (2016). Adoecimento mental em professores brasileiros: Revisão sistemática da literatura. Estudos Interdisciplinares em Psicologia, 7(2), 64-85. Recuperado de http://pepsic.bvsalud.org/scielo.php? script= sci_arttext\&pid=S2236-64072016000200005\&lng = pt\&tlng=pt

Erez, M. (2010). Culture and job design. Journal of Organizational Behavior, 31, 389-400. doi:10.1002/job.651

Ferreira, A. I., Martinez, L. F., Sousa, L. M., \& Cunha, J. V. (2010). Tradução e validação para a língua portuguesa das escalas de presenteísmo WLQ-8 E SPS-6. Avaliação Psicológica, 9(2), 253-266. Recuperado de http://www. redalyc.org/articulo.oa?id $=335027283010$

Frauendorf, R., Pinheiro, M. de M., \& Ciconelli, R. M. (2014). Translation into Brazilian Portuguese, cross-cultural adaptation and validation of the Stanford presenteeism scale- 6 and work instability scale for ankylosing spondylitis. Clinical Rheumatology, 33(12), 1751-1757. doi:10.1007/s100 67-013-2429-6

Gerich, J. (2019). Sickness presenteeism as coping behaviour under conditions of high job control. German Journal of Human Resource Management: Zeitschrift Für Personalforschung, 33(2), 96-112. doi:10.1177/2397002218 794837

Gomes, L. (2002). Trabalho multifacetado de professores/as: A saúde entre limites. (Dissertação de mestrado, Escola Nacional de Saúde, Fundação Osvaldo Cruz, Rio de Janeiro, RJ, Brasil). 
Guise, M. T. (1988). Test of Hackman and Oldham's Job Characteristics Model in a post-secondary educational setting. (Master's thesis). Retrieved from https:// core.ac.uk/download/pdf/62640067.pdf

Hackman, J. R., \& Oldham, G. R. (1975). Development of the Job Diagnostic Survey. Journal of Applied Psychology, 60 (2), 159-170. doi:10.1037/h0076546 Hackman, J. R., \& Oldham, G. R. (1976). Motivation through the design of work: Test of a theory. Organizational Behavior and Human Performance, 16 (2), 250-279. doi:10.1016/0030-5073(76)90016-7

Hemp, P. (2004). Presenteeism: At work-but out of it. Harvard Business Review, 82(10), 49-58.

Johansen, V., Aronsson, G., \& Marklund, S. (2014). Positive and negative reasons for sickness presenteeism in Norway and Sweden: A crosssectional survey. BMJ Open, 4(2), e004123. doi:10.1136/bmjopen-2013004123

Koopman, C., Pelletier, K. R., Murray, J. F., Sharda, C. E., Berger, M. L., Turpin, R. S., \& Bendel, T. (2002). Stanford Presenteeism Scale: Health status and employee productivity. Journal of Occupational and Environmental Medicine, 44(1), 14-20. doi:10.1097/00043764-200201000-00004.

Lesener, T., Gusy, B., \& Wolter, C. (2019). The job demands-resources model: A meta-analytic review of longitudinal studies. Work and Stress, 33(1), 76-103. doi:10.1080/02678373.2018.1529065

Lourenço, V. P. (2016). Absenteísmo, presenteísmo, síndrome de burntout, liderança ética e estratégias de enfrentamento em professores (Dissertação de mestrado, Centro Universitário de Brasília, Brasília, DF, Brasil). Recuperado de https://repositorio.uniceub.br/jspui/handle/235/11145

Molina, M. L., Fialho, A. R., Amaral, P. L., Lima Bach, S., Rocha, L. M., \& Mattos Souza, L. D. (2017). Bem-estar e fatores associados em professores do ensino fundamental no sul do Brasil. Revista CEFAC, 19(6), 812-820. Recuperado de http://www.redalyc.org/articulo.oa?id=169353799010

Moreira, M. A. R. (2015). O burnout e auto-eficácia dos professores: Estudo comparativo entre professores do ensino regular e professores de educação especial (Dissertação de mestrado, Instituto Superior de Ciências Educativas do Douro, Penafiel, Portugal). Recuperado de https://comum.rcaap.pt/bitstream/ 10400.26/24947/1/Tese_Maria\%20Albertina\%20Ribeiro\%20Moreira_ 2015.pdf 
Morgeson, F. P., \& Campion, M. A. (2003). Work design. In W. C. Borman, D. R. Ilgen, \& R. J. Klimoski (Eds.). Handbook of psychology: Industrial and Organizational Psychology (pp. 423-452). Hoboken, NJ: John Wiley \& Sons.

Morgeson, F. P., \& Humphrey, S. E. (2006). The Work Design Questionnaire (WDQ): Developing and validating a comprehensive measure for assessing job design and the nature of work. Journal of Applied Psychology, 91(6), 1321-1339. doi:10.1037/0021-9010.91.6.1321

Organização Mundial do Trabalho (2013). A prevenção das doenças profissionais. Recuperado de http://www.oitbrasil.org.br/sites/default/files/ topic/gender/doc/safeday2013_final_1012.pdf

Ozminkowski, R. J., Goetzel, R. Z., Chang, S., \& Long, S. (2004). The application of two health and productivity instruments at a large employer. Journal of Occupational and Environmental Medicine, 46(7), 635-648. doi:10.10 97/01.jom.0000131797.52458

Parker, S. K. (2014). Beyond motivation: job and work design for development, health, ambidexterity, and more. Annual Review of Psychology, 65(1), 661-691. doi:10.1146/annurev-psych-010213-115208

Parker, S. K., Holman, D., \& Johns, G. (2017). One hundred years of work design research: Looking back and looking forward. Journal of Applied Psychology, 102(3), 403-420. doi:10.1037/apl0000106

Parker, S. K., Knight, C., \& Ohly, S. (2019). The changing face of work design research: Past, present and future directions. In A. Wilkinson, N. Bacon, D. Lepak, \& S. S. (Eds.), The Sage Handbook of Human Resource Management (2nd ed.). London: Sage.

Paschoal, T., \& Tamayo, A. (2008). Construção e validação da escala de bem-estar no trabalho. Avaliação Psicológica, 7(1), 11-22. Recuperado de http:// www.redalyc.org/articulo.oa? id $=335027183004$

Paschoal, T., Torres, C. V., \& Porto, J. B. (2010). Felicidade no trabalho: Relações com suporte organizacional e suporte social. Revista de Administração Contemporânea, 14(6), 1054-1072. doi:10.1590/s1415-65552010000700005

Paschoalin, H. C., Griep, R. H., Lisboa, M. T. L., \& Mello, D. C. B. (2013). Transcultural adaptation and validation of the Stanford Presenteeism Scale for the evaluation of presenteeism for Brazilian Portuguese. Revista Latino-Americana de Enfermagem, 21 (1), 388-395. doi:10.1590/S0104-116920130 00100014

Pereira, N. C. (2014). Presenteísmo odontológico: Conhecendo um instrumento de pesquisa para mensuração e avaliação (Dissertação de mestrado, Universidade 
de São Paulo, Bauru, SP, Brasil). doi:10.11606/D.25.2014.tde-14042015100136

Porto, M. D., Almeida, T. C., \& Teixeira, Z. D. (2013). Condições de trabalho e saúde dos professores das escolas públicas da zona sul da cidade de Manaus. Segundo Congresso Virtual Brasileiro de Administração.

Preacher, K. J., Rucker, D. D., \& Hayes, A. F. (2007). Addressing moderated mediation hypotheses: Theory, methods, and prescriptions. Multivariate Behavioral Research, 42(1), 185-227.

Renn, R. W., \& Vandenberg, R. J. (1995). The critical psychological states: An underrepresented component in Job Characteristics Model research. Journal of Management, 21(2), 279-303. doi:10.1016/0149-2063(95)90059-4

Rocha, F., Sobrinho, \& Porto, J. B. (2012). Bem-estar no trabalho: Um estudo sobre suas relações com clima social, coping e variáveis demográficas. Revista de Administração Contemporânea, 16(2), 253-270. doi:10.1590/s1415-6555 2012000200006

Sampaio, N. S. D. P. (2018). Desenvolvimento profissional, estratégias de aprendizagem e desenho do trabalho (Dissertação de mestrado, Universidade de Brasília, Brasília, DF, Brasil). Recuperado de http://repositorio.unb.br/ handle/10482/33099

Santos, G. B., \& Ceballos, A. G. da C. de. (2013). Bem-estar no trabalho: Estudo de revisão. Psicologia em Estudo, 18(2), 247-255. doi:10.1590/s1 413-73722013000200006

Schaufeli, W. B. (2017). Applying the Job Demands-Resources model: A "how to" guide to measuring and tackling work engagement and burnout. Organizational Dynamics, 46(2), 120-132. doi:10.1016/j.orgdyn.2017.04.008

Siqueira, M. M., \& Padovam, V. A. R. (2008). Bases teóricas de bem-estar subjetivo, bem-estar psicológico e bem-estar no trabalho. Psicologia: Teoria e Pesquisa, 24(2), 201-209. doi: 10.1590/S0102-37722008000200010

Sonnentag, S., \& Frese, M. (2002). Psychological management of individual performance. In S. Sonnentag (Ed.). Psychological management of individual performance (pp. 3-25). London: John Wiley \& Sons.

Sousa, M. S. B. (2016). O presenteísmo e comprometimento organizacional em diferentes setores (Monografia, Centro Universitário de Brasília, Brasília, DF, Brasil).

Tannenbaum, A. S. (1980). Organizational psychology. In H. C. Triandis, \& R. W. Brislin (Eds.). Handbook of cross-cultural psychology (Vol. 5, pp. 281-334). Boston: Allyn and Bacon. 
Vieira, L. da S. (2017). Bem-estar no trabalho e afastamento dos profissionais da educação pública do Distrito Federal. (Dissertação de Mestrado).

Xavier, M. L. S. (2015). A relação entre presenteísmo e comprometimento organizacional de professores (Monografia, Centro Universitário de Brasília, Brasília, DF, Brasil).

Weiss, H. M., \& Cropanzano, R. (1996). Affective events theory: A theoretical discussion of the structure, causes and consequences of affective experiences at work. In B. M. Staw \& L. L. Cummings (Eds.), Research in Organizational Behavior: An Annual Series of Analytical Essays and Critical Reviews (Vol. 18, pp. 1-74). New York: Elsevier Inc.

Zwaan, R. A., Etz, A., Lucas, R. E., \& Donnellan, M. B. (2018). Making replication mainstream. Behavioral and Brain Sciences, 41, e120. doi:10.1017/ S0140525X17001972

\section{AUTHOR NOTES}

Amalia R. Pérez-Nebra, PhD by the Institute of Psychology, Brasília University, (UnB); Fabiana Queiroga, PhD by the Institute of Psychology, Brasília University (UnB); Thiago A. Oliveira, undergraduated at the Faculty of Education and Health Science, Brasília University Center (UniCEUB).

Amalia R. Pérez-Nebra is now full professor at the Department of Psychology and Health of the International University of Valencia; Fabiana Queiroga is now full professor at the Faculty of Education and Health Science of Brasília University Center (UniCEUB); Thiago A. Oliveira is now a master in Psychology student at Brasília University Center (UniCEUB).

Correspondence concerning this article should be addressed to Fabiana Queiroga, SEPN 707/907, campus do UniCEUB, Bloco 9, Asa Norte, Brasília, Distrito Federal, Brazil, CEP 70790-075.

E-mail: fabiana.queiroga@ceub.edu.br

EDITORIAL BOARD

Editors-in-chief

Janette Brunstein

Silvia Marcia Russi De Domênico

Associated Editor

Gardênia da Silva Abbad

Technical Support

Vitória Batista Santos Silva

\section{EDITORIAL PRODUCTION}

Publishing Coordination

Jéssica Dametta

Editorial Intern

Paula Di Sessa Vavlis

Language Editor

Daniel de Almeida Leão
Layout Designer

Emap

Graphic Designer

Libro 